\title{
Further investigations of glucose-6-phosphate dehydrogenase variants in Flores Island, eastern Indonesia
}

\author{
Fumihiko Kawamoto · Hiroyuki Matsuoka - Toshio Kanbe · Indah S. Tantular · \\ Suhintam Pusarawati · Henyo I. Kerong · Wera Damianus · Dominikus Mere · \\ Yoes P. Dachlan
}

Received: 22 May 2006/ Accepted: 26 July 2006/Published online: 23 August 2006

(C) The Japan Society of Human Genetics and Springer-Verlag 2006

\begin{abstract}
We conducted field surveys for malaria and glucose-6-phosphate dehydrogenase (G6PD) deficiency in the eastern part of Flores Island, East Nusa Tenggara Province, Indonesia. A total of 1,108 volunteers (642 males and 466 females) belonging to three ethnic groups (Sikka, Ende and Bajo) were examined, and 55 G6PD-deficient individuals (38 males and 17 females) were detected. Among them, 50 samples were analyzed molecularly, in addition to three deficient cases in a Bajo family. In the Sikka population, G6PD Kaiping $(1388 \mathrm{G}>\mathrm{A})$, one of the two common variants in the Chinese population, was
\end{abstract}

F. Kawamoto $(\square)$

Institute of Scientific Research, Faculty of Medicine,

Oita University, Yufu, Japan

e-mail: hiko@med.oita-u.ac.jp

H. Matsuoka

Division of Medical Zoology,

Department of Infection and Immunity,

Jichi Medical University, Shimotsuke, Japan

T. Kanbe

Department of Advanced Medical Science,

Nagoya University Graduate School of Medicine,

Showa, Nagoya, Japan

I. S. Tantular · S. Pusarawati · Y. P. Dachlan

Tropical Disease Center, Airlangga University, Surabaya,

Indonesia

H. I. Kerong · W. Damianus

Health Department, Maumere, Sikka District,

East Nusa Tenggala Province, Indonesia

D. Mere

Health Department, Ende, Ende District,

East Nusa Tenggala Province, Indonesia unexpectedly found as the most dominant variant $(11 / 22, \quad 50.0 \%)$, followed by G6PD Chatham (1003G $>$ A, 36.4\%), G6PD Coimbra (592C $>$ T, 9.1\%) and G6PD Vanua Lava (383T $>$ C, $4.5 \%)$. Frequency of G6PD Kaiping in the Sikka might be the highest among non-Chinese populations reported so far. In the Ende population, G6PD Vanua Lava (9/14, $64.3 \%$ ) was the highest, followed by G6PD Kaiping (14.3\%), G6PD Chinese-5 (1024C >T, 14.3\%) and G6PD Chatham (7.1\%). In the Bajo population, a total of 18 deficient cases were analyzed, and a novel mutation $(844 \mathrm{G}>\mathrm{T})$ in exon 8 with a predicted amino acid change of 282 Asp>Tyr was found in a 7-yearold boy at a Bajo village near Maumere. This new Class II (mild type) variant was also confirmed in his mother and sister, and designated as G6PD Bajo Maumere. The missense mutation at the same nucleotide 844 has been known as G6PD Seattle/ Lodi/Modena/Ferrara II, but this mutation is caused by a $\mathrm{G}>\mathrm{C}$ substitution (282 Asp $>$ His). In the Bajo population, G6PD Viangchan (871G $>$ A, IVS $11 \mathrm{nt} 93$ $\mathrm{T}>\mathrm{C}, 1311 \mathrm{C}>\mathrm{T})$, the most common variant in continental Southeast Asian populations, was found to be the dominant $(11 / 18,61.1 \%)$, followed by G6PD Vanua Lava and the new variant (each $16.7 \%$ ), and G6PD Coimbra (5.6\%). These results strongly suggest that the Bajo peoples may have different ancestors from those for Sikka and Ende, and may be much closer to continental Southeast Asian populations. It is interesting that G6PD Canton $(1376 \mathrm{G}>\mathrm{T})$, another common variant in Chinese, was not seen in the Flores population.

Keywords G6PD deficiency $\cdot$ New variant $\cdot$ Bajo · Sikka Ende $\cdot$ Maumere $\cdot$ Flores Island $\cdot$ Indonesia 


\section{Introduction}

Glucose-6-phosphate dehydrogenase (G6PD) deficiency is one of the most frequent hereditary disorders in the world. This enzyme is encoded in 13 exons with an open reading frame of $1,545 \mathrm{bp}$ (Chen et al. 1991). Most G6PD deficiency is caused by a single nucleotide mutation, resulting in one amino-acid change among 515. To date, more than 400 G6PD biochemical variants have been described, and at least 140 mutations of G6PD deficiency have been discovered (Beutler and Vulliamy 2002).

The major G6PD variants reported in Southeast Asian countries are G6PD Viangchan $(871 \mathrm{G}>\mathrm{A}$, IVS 11 nt93 T>C, 1311C $>$ T) and G6PD Mahidol $(487 \mathrm{G}>\mathrm{A})$, but the distribution of G6PD mutation differs in each country. For instance, almost all of G6PD deficient cases detected in Laos (Iwai et al. 2001) and Cambodia (Louicharoen and Nuchprayoon 2005; Matsuoka et al. 2005) are G6PD Viangchan. This variant is also the most common in Thais $(54 \%$, Nuchprayoon et al. 2002; 31.3\%, Laosombat et al. 2005) and Malaysian Malays (37.2\%, Ainoon et al. 2003 ), suggesting that this is a common ancestral origin of continental Southeast Asian populations. In Myanmar, however, G6PD Viangchan has never been reported, and more than $90 \%$ of variants are G6PD Mahidol (Iwai et al. 2001; Matsuoka et al. 2004; Than et al. 2005). This type is also common in Thailand ( $8 \%$, Nuchprayoon et al. 2002; 17.2\%, Laosombat et al. $2005)$ and among Malaysian Malays (15.1\%, Ainoon et al. 2003), but not reported in Laos and Cambodia.

In Thailand and Malaysia, many other variants derived from Chinese immigrants such as G6PD Canton (1376G>T), G6PD Kaiping (1388G>A), G6PD Gaohe $(95 A>G)$ are also distributing. Furthermore, variants derived from Europe (G6PD Mediterranean, 563C $>\mathrm{T}$ ), the Middle East to India (G6PD Chatham, 1003G $>$ A) and Oceania (G6PD Vanua Lava, 383T $>$ C; G6PD Union, $1360 \mathrm{C}>\mathrm{T}$ ), are commonly detected in both countries.

In Indonesia, numerous ethnic groups are present, and thus many G6PD variants might be included as seen in Thailand and Malaysia. In fact, five cases of G6PD Mediterranean, three of G6PD Canton, two of G6PD Mahidol and one of G6PD Coimbra (592C > T) have been reported in Javanese (Soemantri et al. 1995; Iwai et al. 2001). Furthermore, we have reported 11 cases of G6PD Vanua Lava in Amboinese on Buru and Halmahera Islands, and five mixed variants of G6PD Canton, G6PD Kaiping, G6PD Gaohe, G6PD Chatham and G6PD Surabaya $(1291 \mathrm{G}>\mathrm{A})$ in ethnic Chinese on Surabaya (Iwai et al. 2001). In the Sikka population on Flores Island, we have also identified five different variants (G6PD Chatham, G6PD Kaiping, G6PD Coimbra, G6PD Vanua Lava, G6PD Viangchan) in a small area (Matsuoka et al. 2003).

Following these previous studies in Indonesia, we conducted further field surveys for malaria and G6PD deficiency in Sikka and Ende districts, eastern Flores Island. Here, we report seven G6PD variants from three ethnic groups, including a novel mutation found in a family of the Bajo (Sea Gypsy) who have their own language and have never married into other tribes until recently.

\section{Materials and methods}

This study was approved by the Health Departments of Sikka and Ende districts, East Nusa Tenggara Province, and by the Ethical Committees of Jichi Medical University and Oita University Faculty of Medicine, Japan.

During March 2004 to December 2005, we surveyed malaria and G6PD deficiency in villages near Maumere (Sikka district; population ca. 260,000) and Ende (Ende district; population ca. 240,000), Flores Island (Fig. 1). Informed consent was obtained from each febrile volunteer before diagnoses of malaria and G6PD deficiency.

Febrile volunteers were first registered by name, age, gender, and ethnicity. Then, three drops of blood were collected from the fingertip: one for malaria diagnosis, one for hemoglobin concentration, and one for G6PD test. Malaria was diagnosed by acridine orange staining method (Tantular et al. 1999; Matsuoka et al. 2003), and hemoglobin concentration was measured using a battery-powered, HemoCue machine (Angelhorm, Sweden). For diagnosis of G6PD deficiency, we used a rapid diagnostic method (Tantular and Kawamoto 2003; Jalloh et al. 2004). When malaria patients or G6PD deficient individuals were detected, informed consent was again obtained, and $0.2-2.0 \mathrm{ml}$ of venous blood was taken for further molecular analysis.

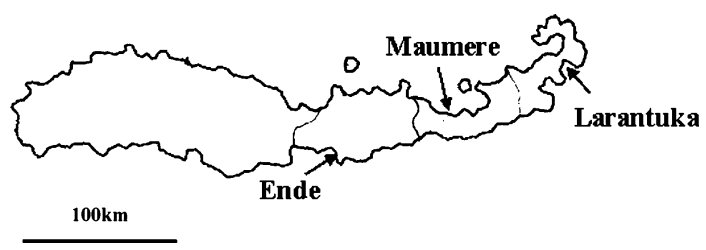

Fig. 1 Map of Sikka and Ende districts, Flores Island 
Blood samples collected were stored at $4{ }^{\circ} \mathrm{C}$ and brought back to Jichi Medical University, and G6PD activity was re-confirmed by another G6PD test developed by Fujii et al. (1984). Then, G6PD mutation was identified by sequencing both strands of G6PD gene (Matsuoka et al. 2004; 2005). Epidemiological data for malaria infection obtained in this study will be reported in elsewhere.

\section{Results and discussion}

On Flores Island, eight major ethnicities, Manggarai, Riung, Ngada (Bajawa), Nage-Keo, Palue, Ende (Ende-Lio), Sikka and Larantuka (see Fig. 1), are present as indigenous islanders, and they have their own languages. Except for the Manggarai (the westernmost) and the Larantuka (the easternmost), the other six tribes are thought to be very close each other.

In Sikka and Ende districts, a total of 1,108 volunteers (642 males and 466 females) belonging to ethnic groups of Sikka, Ende and Bajo were examined, and 38 males and 17 females were identified as G6PD deficient (Table 1). Among them, we obtained informed consent from 50 volunteers for further analysis of the G6PD gene. As shown in Table 2, a total of seven different variants, including G6PD Vanua Lava, G6PD Coimbra, G6PD Viangchan, G6PD Chatham, G6PD Chinese-5, G6PD Kaiping and a new variant, G6PD Bajo Maumere (844G $>$ T), were identified.

In our previous study (Matsuoka et al. 2003), we reported the five different variants in the Sikka population at Maumere and Talibura (40 km east from Maumere), and a similar combination of variants was again observed in this survey at Nangahure and Magepanda, $10-30 \mathrm{~km}$ west from Maumere. Four variants among the five, except G6PD Viangchan, were detected (Table 2), but the frequency distribution of G6PD variants was little different from that in the previous study. This may be caused either because of a small sample size and/or because of a possible heter-

Table 1 The incidence of glucose-6-phosphate dehydrogenase deficiency in various ethnic groups in eastern Flores Island

\begin{tabular}{lcccc}
\hline Ethnic group & Sikka & Ende & Bajo & Total \\
\hline Male & & & & \\
Number of samples & 224 & 177 & 241 & 642 \\
Number of deficiency & 19 & 7 & 12 & 38 \\
Incidence (\%) & 8.5 & 4.0 & 5.0 & 5.9 \\
Female & & & & \\
Number of samples & 161 & 186 & 119 & 466 \\
Number of deficiency & 5 & 9 & 3 & 17 \\
Incidence (\%) & 3.1 & 4.8 & 2.5 & 3.6 \\
\hline
\end{tabular}

ogeneity within the Sikka tribe. Surprisingly, however, G6PD Kaiping, one of the two common variants in Chinese population, was dominant $(50.0 \%)$, followed by G6PD Chatham (36.4\%). The presence of G6PD Kaiping in non-Chinese populations has been reported in Thais $(2 / 39,5 \%$ in Bangkok, Nuchprayoon et al. 2002; 27/134, 20.1\% in southern Thai, Laosombat et al. 2005; 1/9, 11.1\% in southern island, Ninokata et al. 2006), Malays (2/86, 2.3\%, Ainoon et al. 2003), and Papuans (1/4, 25\%, Wagner et al. 1996). Total frequency of G6PD Kaiping in the Sikka population reached $42.4 \%(14 / 33)$, and this value may be the highest among non-Chinese populations reported so far. From historical and religious backgrounds, it is easily presumed that Chinese traders or immigrants have merged closely with Christian Sikka women and so introduced this mutated gene into the Sikka population.

In the Ende population, the prevalence of G6PD deficiency was higher in females than in males for unknown reasons (Table 1). G6PD Kaiping and Chatam were also detected among them, but G6PD Vanua Lava was the most common (64.3\%). G6PD Chinese-5 was also detected in two sisters (Table 2): a 6-year-old girl was heterozygous with double variants of G6PD Chinese-5 and Vanua Lava, whereas her 7-year-old sister was heterozygous with G6PD Chinese-5. As they have a Chinese father and an Ende mother, two mutated genes of G6PD Chinese-5 and Vanua Lava were apparently derived from their father and mother, respectively. The Ende are neighbors to the Sikka, and they are thought to be very close to each other. However, their territories are separated by steep mountains, and they have different languages. Our results on frequency distribution of G6PD variants between these two tribes suggest that their origins may be more complicated than we expected.

High frequency distribution of G6PD Kaiping in the Sikka is a rather unexpected finding. In contrast, G6PD Canton, another common variant in Chinese population, was never seen in the Sikka nor in the Ende. Many surveillances of G6PD deficiency in Chinese, Thai, and Malay populations, conducted in China, Taiwan, Thailand, Malaysia and Singapore, have revealed that frequency of G6PD Canton is higher than that of G6PD Kaiping (Chang et al. 1992; Huang et al. 1996; Chiang et al. 1999; Ainoon et al. 1999; Nuchprayoon et al. 2002) or they are almost equal (Chiu et al. 1993; Quak et al. 1996; Ainoon et al. 2003, 2004; Jiang et al. 2005, 2006). Therefore, it is interesting why G6PD Canton was not detected in the Sikka or Ende populations. In addition, another remarkable finding observed in our studies was that G6PD Viangchan or 
Table 2 Glucose-6-phosphate dehydrogenase variants detected in the present and previous studies

\begin{tabular}{|c|c|c|c|c|c|}
\hline \multirow[t]{2}{*}{ Nucleotide change } & \multirow[t]{2}{*}{ Name of variant } & \multicolumn{4}{|c|}{ Number identified } \\
\hline & & Sikka & Ende & Bajo $^{a}$ & Total \\
\hline $383 \mathrm{~T}>\mathrm{C}$ & Vanua Lava & $1(1)^{b}$ & $9^{c}$ & 3 & 13 \\
\hline $592 \mathrm{C}>\mathrm{T}$ & Coimbra & $2(5)$ & 0 & 1 & 3 \\
\hline $844 \mathrm{G}>\mathrm{T}$ & Bajo Maumere (new) & $0(0)$ & 0 & 3 & 3 \\
\hline $871 \mathrm{G}>\mathrm{A}$ & Viangchan ${ }^{\mathrm{d}}$ & $0(1)$ & 0 & 11 & 11 \\
\hline $1003 \mathrm{G}>\mathrm{A}$ & Chatham & $8(1)$ & 1 & 0 & 9 \\
\hline $1024 \mathrm{C}>\mathrm{T}$ & Chinese-5 & $0(0)$ & $2^{\mathrm{c}}$ & 0 & 2 \\
\hline $1388 \mathrm{G}>\mathrm{A}$ & Kaiping & $11(3)$ & 2 & 0 & 13 \\
\hline Total & & $22(11)$ & 14 & 18 & 54 \\
\hline
\end{tabular}

a Three deficient individuals in a family of a boy with G6PD Bajo Maumere were included (see text)

${ }^{b}$ Numbers in parentheses indicate those of each G6PD variant detected in our previous study (Matsuoka et al. 2003)

${ }^{c}$ A girl was heterozygous with G6PD Chinese-5 and Vanua Lava, and her sister was heterozygous with G6PD Chinese-5 (see text)

d Two more non-sense mutations at $1311 \mathrm{C}>\mathrm{T}$ in exon 11 and at $\mathrm{nt} 93 \mathrm{~T}>\mathrm{C}$ in intron 11 were confirmed

Mahidol, the most common variants in continental Southeast Asian populations, was very rare in both populations (only $1 / 47 ; 2.1 \%$ ), indicating that the Sikka and Ende (and also Amboinese) may have different ancestors from those of continental Southeast Asian populations.

On the other hand, the Bajo (Bajau) are one of the sea nomads (Sea Gipsy), inhabiting the area between eastern Malaysia (Sabah State, Kalimantan Island) and central to eastern Indonesia (Sulawesi, Sumbawa and Flores Islands). This ethnic group also belongs to the Malayo-Polynesians, the same as Javanese, Amboinese, Sikka and Ende, and are thought to have originated from south Mindanao, Philippines (Fox 1997). Over the last 300 years, they have migrated from south Mindanao, and scattered into small settlements in many coastal areas. Until quite recently, the Bajo peoples were very isolated, since their settlements were apart from native villages, they spoke only Bajo (or Samal), and never married with any other tribe. Therefore, we expected the existence of a unique G6PD variant or unique combination of G6PD variants in the Bajo population, differing from those of the Sikka, Ende, Amboinese or Javanese.

As expected, we found a novel variation from a 7year-old boy in a Bajo village (Wuring village, $4 \mathrm{~km}$ west of Maumere; population ca. 4,000). A missense mutation was seen at nucleotide 844 ( $\mathrm{G}$ to $\mathrm{T}$ ) in the exon 8 with a predicted amino-acid change of 282 Asp $>$ Tyr (Fig. 2a). To confirm this new variant, we further examined G6PD activities in his family. His mother (31 years old) and one (5 years old) of two young sisters were found to be heterozygous with this variant (Fig. 2b), whereas a cousin of his mother was identified as hemizygous with G6PD Viangchan. The new variant was categorized as Class II (mild type), and we designated this new variant as G6PD Bajo Maumere.

The missense mutation at the same nucleotide 844 has been known as G6PD Seattle/Lodi/Modena/Ferrara II, but this mutation is caused by a substitution from G to C (282 Asp>His, Beutler and Vulliamy 2002). Sharing two different G6PD variants by two

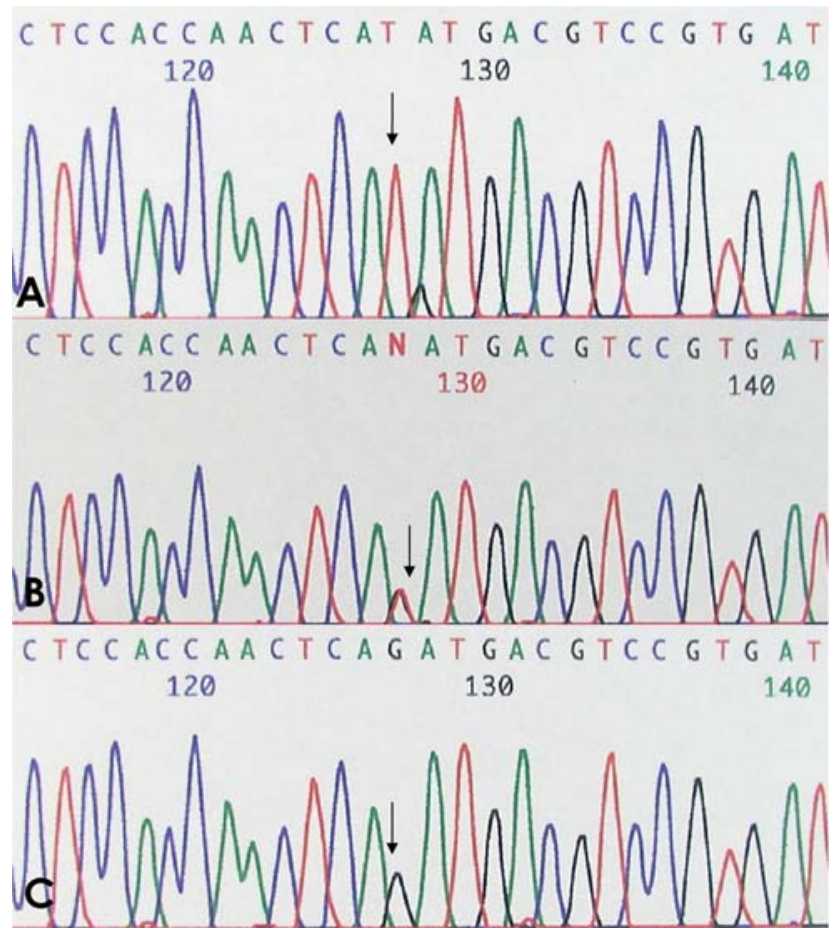

Fig. 2 a Part of the DNA sequence in the exon 8 from a hemizygous boy with G6PD Bajo Maumere. b Part of the DNA sequence in the exon 8 from a heterozygous mother with G6PD Bajo Maumere. c Part of the DNA sequence in the exon 8 from his young sister with normal G6PD. Arrows show 844 T, 844 T/G, and $844 \mathrm{G}$, respectively 
different mutations at the same nucleotide has been found between G6PD A- $(680 \mathrm{G}>\mathrm{T}, 376 \mathrm{~A}>\mathrm{G})$ and Mexico City (680G $>A)$, G6PD Chinese-1 (835A $>$ T) and Haikou $(835 \mathrm{~A}>\mathrm{G})$, G6PD Loma Limda $(1089 \mathrm{C}>\mathrm{A})$ and Aachen $(1089 \mathrm{C}>\mathrm{G})$, G6PD Olomouc $(1141 \mathrm{~T}>\mathrm{C})$ and New York $(1141 \mathrm{~T}>\mathrm{A})$, G6PD Kawasaki $(1229 \mathrm{G}>\mathrm{C})$ and Japan $(1229 \mathrm{G}>\mathrm{A})$, G6PD Canton $(1376 \mathrm{G}>\mathrm{T})$ and Cosenza $(1376 \mathrm{G}>\mathrm{C})$ (Beutler and Vulliamy 2002).

Among a total of 18 deficient cases analyzed in the Bajo population, G6PD Viangchan was the highest (61.1\%), followed by G6PD Vanua Lava and the new variant (each 16.7\%), and G6PD Coimbra (5.6\%). All these results taken together indicate that the Bajo is absolutely different from the Sikka, Ende, Amboinese or Javanese, and might be closer to ethnic groups in continental Southeast Asian populations, having the most common variant of G6PD Viangchan. It is of interest to note that, in the Moken population, another Sea Gypsy living in costal areas in Myanmar and Thailand, G6PD Mahidol $(11 / 17,64.7 \%)$ is the most common variant, followed by G6PD Viangchan (4/17, $23.5 \%$ ) (Ninokata et al. 2006).

Acknowledgments We thank Mrs. Midori Sato, Jichi Medical University, for technical assistance. This work was supported by the Grant-in-Aid for Scientific Research from the Japan Society for Promotion of Science (15406014/16590341/17406010 to F.K. and 14406026 to H.M.).

\section{References}

Ainoon O, Joyce J, Boo NY, Cheong SK, Zainal ZA, Hamidah NH (1999) Glucose-6-phosphate dehydrogenase (G6PD) variants in Malaysian Chinese. Hum Mutat 14:352

Ainoon O, Yu YH, Amir Muhriz AL, Boo NY, Cheong SK, Hamidah NH (2003) Glucose-6-phosphate dehydrogenase (G6PD) variants in Malaysian Malays. Hum Mutat 21:101. DOI 10.1002/humu.9103

Ainoon O, Boo NY, Yu YH, Cheong SK, Hamidah HN, Lim JH (2004) Complete molecular characterisation of glucose-6phosphate dehydrogenase (G6PD) deficiency in a group of Malaysian Chinese neonates. Malays J Pathol 26:89-98

Beutler E, Vulliamy TJ (2002) Hematologically important mutations: glucose-6-phosphate dehydrogenase. Blood Cells Mol Dis 28:93-103. DOI 10.1006/bcmd.2002.0490

Chang JG, Chiou SS, Perng LI, Chen TC, Liu TC, Lee LS, Chen PH, Tang TK (1992) Molecular characterization of glucose6-phosphate dehydrogenase (G6PD) deficiency by natural and amplification created restriction sites: five mutations account for most G6PD deficiency cases in Taiwan. Blood 80:1079-1082

Chen EY, Cheng A, Lee A, Kuang WJ, Hillier L, Green P, Schlessinger D, Ciccodicola A, D'Urso M (1991) Sequence of human glucose-6-phosphate dehydrogenase cloned in plasmids and a yeast artificial chromosome. Genomics 10:792-800. DOI 10.1016/0888-7543(91)90465-Q
Chiang SH, Wu SJ, Wu KF, Hsiao KJ (1999) Neonatal screening for glucose-6-phosphate dehydrogenase deficiency in Taiwan. Southeast Asian J Trop Med Public Health 30(Suppl 2):72-74

Chiu DTY, Zuo L, Chao L, Chen E, Louie E, Lubin B, Liu TZ, Du CS (1993) Molecular characterization of glucose-6phosphate dehydrogenase (G6PD) deficiency in patients of Chinese descent and identification of new base substitutions in the human G6PD gene. Blood 81:2150-2154

Fox JJ (1997) History and people: the flow of life in Nusa Tenggara. In: Muller K, Pickell D (eds) East of Bali from Lombok to Timor. Periplus Editions, Hong Kong, pp 30-35

Fujii H, Takahashi K, Miwa S (1984) A new simple screening method for glucose 6-phosphate dehydrogenase deficiency. Acta Haematol Jpn 47:185-188

Huang CS, Hung KL, Huang MJ, Li YC, Liu TH, Tang TK (1996) Neonatal jaundice and molecular mutations in glucose-6-phosphate dehydrogenase deficient newborn infants. Am J Hematol 51:19-25

Iwai K, Hirono A, Matsuoka H, Kawamoto F, Horie T, Lin K, Tantular IS, Dachlan YP, Notopuro H, Hidayah NI, Salim AM, Fujii H, Miwa S, Ishii A (2001) Distribution of glucose6-phosphate dehydrogenase mutations in Southeast Asia. Hum Genet 108:445-449

Jalloh A, Tantular IS, Pusarawati S, Kawilarang AP, Kerong H, Lin K, Ferreira MU, Matsuoka H, Arai M, Kita K, Kawamoto F (2004) Rapid epidemiologicassessment of glucose-6-phosphate dehydrogenase (G6PD) deficiency in malaria-endemic areas in Southeast Asia using a novel diagnostic kit. Trop Med Int Health 9:615-623. DOI 10.1111/j.1365-3156.2004.01237.x

Jiang WY, Chen LM, Lin QD, Geng Q, Du CS (2005) Denaturing high-performance liquid chromatography technique platform applied to screen G6PD deficient variants. Zhonghua Yi Xue Yi Chuan Xue Za Zhi 22:607-611

Jiang W, Yu G, Liu P, Geng Q, Chen L, Lin Q, Ren X, Ye W, He Y, Guo Y, Duan S, Wen J, Li H, Qi Y, Jiang C, Zheng Y, Liu C, Si E, Zhang Q, Tian Q, Du C (2006) Structure and function of glucose-6-phosphate dehydrogenase-deficient variants in Chinese population. Hum Genet 119:463-478. DOI 10.1007/s00439-005-0126-5

Laosombat V, Sattayasevana B, Janejindamai W, Viprakasit V, Shirakawa T, Nishiyama K, Matsuo M (2005) Molecular heterogeneity of glucose-6-phosphate dehydrogenase (G6PD) variants in the south of Thailand and identification of a novel variant (G6PD Songklanagarind). Blood Cells Mol Dis 34:191-196. DOI 10.1016/j.bcmd.2004.11.001

Louicharoen C, Nuchprayoon I (2005) G6PD Viangchan $(871 \mathrm{G}>\mathrm{A})$ is the most common G6PD-deficient variant in the Cambodian population. J Hum Genet 50:448-452. DOI 10.1007/s10038-005-0276-2

Matsuoka H, Arai M, Yoshida S, Tantular IS, Pusarawati S, Kerong H, Kawamoto F (2003) Five different glucose-6phophate dehydrogenase (G6PD) variants found among 11 G6PD-deficient persons in Flores Island, Indonesia. J Hum Genet 48:541-544. DOI 10.1007/s10038-003-0073-8

Matsuoka H, Wang J, Hirai M, Arai M, Yoshida S, Kobayashi T, Jalloh A, Lin K, Kawamoto F (2004) Glucose-6-phosphate dehydrogenase (G6PD) mutations in Myanmar: G6PD Mahidol $(487 \mathrm{G}>\mathrm{A})$ is the most common variant in the Myanmar population. J Hum Genet 49:544-547. DOI 10.1007/s10038-004-0187-7

Matsuoka H, Nguon C, Kanbe T, Jalloh A, Sato H, Yoshida S, Hirai H, Arai M, Socheat D, Kawamoto F (2005) Glucose-6phosphate dehydrogenase (G6PD) mutations in Cambodia: 
G6PD Viangchan $(871 \mathrm{G}>\mathrm{A})$ is the most common variant in the Cambodian population. J Hum Genet 50:468-472. DOI 10.1007/s10038-005-0279-z

Ninokata A, Kimura R, Samakkarn U, Settheetham-Ishida W, Ishida T (2006) Coexistence of five G6PD variants indicates ethnic complexity of Phuket islanders, Southern Thailand. J Hum Genet 51:424-428. DOI 10.1007/s10038-006-0380-y

Nuchprayoon I, Sanpavat S, Nuchprayoon S (2002) Glucose-6phosphate dehydrogenase (G6PD) mutations in Thailand: G6PD Viangchan $(871 \mathrm{G}>\mathrm{A})$ is the most common deficiency variant in the Thai population. Hum Mutat 19:185

Quak SH, Saha N, Tay JS (1996) Glucose-6-phosphate dehydrogenase deficiency in Singapore. Ann Acad Med Singap 25:45-48

Soemantri AG, Saha S, Saha N, Tay JS (1995) Molecular variants of red cell glucose-6-phosphate dehydrogenase deficiency in Central Java, Indonesia. Hum Hered 45:346-350
Tantular IS, Kawamoto F (2003) An improved, simple screening method for detection of glucose-6-phosphate dehydrogenase deficiency. Trop Med Int Health 8:569-574

Tantular IS, Iwai K, Lin K, Basuki S, Horie T, Htay HH, Matsuoka H, Marwoto H, Wongsrichanalai C, Dachlan YP, Kojima S, Ishii A, Kawamoto F (1999) Field trials of a rapid test forG6PD deficiency in combination with a rapid diagnosis of malaria. Trop Med Int Health 4:245-250

Than AM, Harano T, Harano K, Myint AA, Ogino T, Okada S (2005) High incidence of 3-thalassemia, hemoglobin E, and glucose-6-phosphate dehydrogenase deficiency in populations of malaria-endemic Southern Shan State, Myanmar. Int J Hematol 82:119-123

Wagner G, Bhatia K, Board P (1996) Glucose-6-phosphate dehydrogenase deficiency mutations in Papua New Guinea. Hum Biol 68:383-694 